\title{
Management of HIV in Pregnancy: A Clinical Review
}

\author{
Chris. O. Agboghoroma
}

Department of Obstetrics \& Gynaecology, National Hospital Abuja, Nigeria.

\begin{abstract}
Context: The prevalence rate of HIV infection in pregnant women in some African countries is over 30 percent. HIV may adversely affect pregnancy outcome leading to spontaneous abortion, premature delivery, intrauterine growth restriction and low birth weight infants. The natural perinatal transmission risk varies from $15-45 \%$. With improved scientific knowledge in antiretroviral therapy, obstetric care and infant feeding practices, it is now possible to achieve and sustain satisfactory maternal health and prevent perinatal transmission. The application of these strategies has resulted in substantial reduction in perinatal transmission risks (less than $2 \%$ ) in developed countries.

Objective: This article reviews the specific strategies in the management of HIV positive pregnant woman. It is also meant to serve as guide to health workers who provide care for HIV positive pregnant women.

Methodology: Extensive literature search and review of journal/internet articles, WHO publications, international and local guidelines on management of HIV in pregnancy.

Conclusion: Within the setting of maternity services, HIV positive women can be diagnosed and managed appropriately. The care should be multidisciplinary, sensitive, non-stigmatizing, non-discriminatory and supportive. The capacity to achieve this can be developed through training and retraining of health care workers.
\end{abstract}

Key Words: Human immunodeficiency virus, HIV, pregnancy, perinatal transmission, [Trop J Obstet Gynaecol, 2005, 22: 65-73]

\section{Introduction}

High prevalence rate of Human Immunodeficiency Virus (HIV) infection in pregnant women have been reported in many countries. In some African countries the prevalence rate is over $30 \%{ }^{\prime}$. In Nigeria, hospital studies and national sero-prevalence surveys among pregnant women showed rising trends over the years ${ }^{2-4}$. The 2003 national sero-prevalance survey gave a prevalence rate ranging from $1.2 \%$ to $12.0 \%$ in the states and a national median value of $5.0 \%$.

HIV infection leads to acquired immune deficiency syndrome (AIDS), which is fatal when not properly managed. The first AIDS case was reported in United States in 1981 and the causative virus identified in 1983. There are two main types of HIV; HIV type 1 (HIV-1) is the most common globally and more virulent while HIV type 2 (HIV-2) is found predominantly in West Africa. HIV has attracted enormous and unparalleled research effort. Although, there is yet no vaccine or cure for HIV infection, much progress have been made in the characterization of the virus, its pathogenesis, diagnosis and treatment. With the current use of highly active antiretroviral therapy (HAART) regimen; mortality from HIV/AIDS has been drastically reduced and HIV is now regarded as a manageable chronic disease.

The scientific knowledge on HIV in pregnancy has been particularly impressive. A number of important randomized controlled trials make it one of the most clearly evidence based subject in pregnancy management. Studies that have examined the potential impact of pregnancy on HIV disease have consistently shown no significant differences in HIV progression or survival (using virologic, immunologic and clinical parameters) between women who had been pregnant and those who have not experienced pregnancy". However, maternal HIV infection has been associated with pregnancy adverse outcomes which include spontaneous abortion, preterm delivery, intrauterine growth restriction (IUGR) and low birth weight (LBW) infants'. These complications are related to advanced disease states (or their treatment), presence of other infections and poor nutritional status. Furthermore, HIV adversely affects the frequency, natural history, presentation and treatment of many infections in pregnancy including vulvo-vaginal candidiasis, bacterial vaginosis, genital herpes simplex, human papiloma virus (HPV), syphilis, trichomonas vaginalis, cytomegalovirus, toxoplasmosis, hepatitis $\mathrm{B}$ and $\mathrm{C}$, malaria, urinary tract infections and bacteria pneumonia. In addition to these infections and parasitic infestations, any of the HIV-related opportunistic infections - such as tuberculosis, pneumocystis carinii pneumonia etc. are more frequent during pregnancy and in the puerperium.

Another critical concern about HIV in pregnancy is the potential for perinatal or mother-to-child transmission (MTCT). Perinatal transmission accounts for $90 \%$ of global $(640,000$ new cases in 2004) pediatric HIV infections ${ }^{8}$. Transmission may occur during the period

Correspondence: Dr Chris. O. Agboghoroma, Department of Obstetrics \& Gynaecology, National Hospital Abuja, P.M.B. 425 Garki, Abuja, Nigeria.

E-mail:agboschris@yahoo.com 
of pregnancy, labour and delivery or breast-feeding through the placenta, breaks in the skin, mucous membrane, gastro-intestinal tract and breastmilk.

Without interventions, the risk of perinatal transmission ranges from 15 to $25 \%$ in developed countries and from 25 to $45 \%$ in developing countries ${ }^{10}$. Studies have shown that in non-breastfed infants, $65 \%$ were infected around the time of labour and delivery and $35 \%$ in utero $^{11,12}$. In breastfeeding populations, $30-50 \%$ of infected infants contract their infection during the period of breast feeding ${ }^{13}$.

Many factors (maternal, obstetrics, fetal and breastfeeding) have been associated with increased risk of perinatal transmission. The maternal factors include high viral load, low $\mathrm{CD}_{4}$ count, presence of sexually transmitted infections, unprotected sexual intercourse with multiple sexual partners, heroin or cocaine use and vitamin A deficiency during the periods of pregnancy and puerperium ${ }^{14-20}$. Hemorrhage and invasive procedures during pregnancy and delivery, and prolonged rupture of fetal membranes ( $>$ hhours) are incriminated obstetrics factors ${ }^{21-23}$. The fetal factors include prematurity and fetal injury ${ }^{24}$. The difference in perinatal transmission rates between the developed and developing countries is largely attributed to the practice of breastfeeding in the latter. The length of breastfeeding correlates with infection risk ${ }^{25-27}$.

The management of HIV infection in pregnancy has evolved over time. It has not been possible to effectively manage HIV infection during pregnancy and prevent perinatal transmission until recently. There were concerns about potential teratogenic and mutagenic effects with use of antiretroviral drugs in pregnancy ${ }^{23-30}$. However, with improved scientific knowledge and experience in antiretroviral therapy, obstetric care and infant feeding practices, the situation has changed. It is now possible to achieve and sustain satisfactory maternal health and prevent perinatal transmission. The application of these strategies has resulted in substantial reduction in perinatal transmission risks (less than $2 \%$ ) in developed countries ${ }^{31}$. Many constraints however, exist in implementing these interventions in many developing countries ${ }^{32,33}$

This article outlines the specific issues in the management of HIV positive pregnant woman. It is also meant to serve as a guide to health workers who provide care for pregnant women that are HIV positive.

\section{Diagnosis of HIV}

The diagnosis of HIV infection is based on the detection of the virus or viral protein or antibodies in the blood or body fluid. Table I shows the diagnostic and monitoring tests for HIV infection. The majority of HIV infected persons are asymptomatic. As such the need to identify HIV positive pregnant women that should benefit from interventions have necessitated testing of patients during the antenatal period.

Table 1

Diagnostics and Monitoring Tests for HIV Infection.

\begin{tabular}{|c|c|c|}
\hline Test & Nature & Comment \\
\hline $\begin{array}{l}\text { Enzyme liked immunosorbent } \\
\text { Assay(ELISA) tests }\end{array}$ & Antibody test & $\begin{array}{l}\text { Diagnostic } \\
\text { (Screening) }\end{array}$ \\
\hline Simple/rapid HIV test & Antibody test & $\begin{array}{l}\text { Diagnostic } \\
\text { (Screening) }\end{array}$ \\
\hline Western Blot (WB) & Antibody test & $\begin{array}{c}\text { Diagnostic } \\
\text { (Confirmatory) }\end{array}$ \\
\hline$P_{24}$ Antigen test & Antigen (Viralprotein) & $\begin{array}{c}\text { Diagnostic } \\
\text { (Confirmatory) }\end{array}$ \\
\hline RNA PCR (Quantitative) & Viral test & $\begin{array}{l}\text { Diagnostic, may } \\
\text { be used for monitoring }\end{array}$ \\
\hline DNA PCR (Qualitative) & Viral test & Diagnostic \\
\hline Viral Culture & Viral test & Diagnostic \\
\hline $\mathrm{CD}_{4}$ Count & $\begin{array}{l}\text { Immunological } \\
\text { Monitoring of status }\end{array}$ & Immunological test \\
\hline $\mathrm{CD}_{8}$ Count & $"$ & $"$ \\
\hline $\mathrm{CD}_{4} / \mathrm{CD}_{\mathrm{k}}$ ratio & $"$ & $"$ \\
\hline $\mathrm{CD}_{4}$ Percentage & $"$ & $"$ \\
\hline
\end{tabular}




\section{Table 2}

Criteria for Initiation and Pre-treatment Evaluation for Antiretroviral therapy.

\section{Criteria for Initiation of Antiretroviral therapy.}

If $\mathrm{CD}_{4}$ cell count is available:

- WHO stage IV disease irrespective of $\mathrm{CD}_{4}$ cell count

- WHO stage III disease with $\mathrm{CD}_{4}$ cell count $<350$ cells $/ \mathrm{mm}^{3}$

- WHO stage I or II disease with $\mathrm{CD}_{4}$ cell count $<$ or $=200 \mathrm{cells} / \mathrm{mm}^{3}$

\section{If $C D 4$ cell count is unavailable:}

- WHO stage IV disease irrespective of total lymphocyte count (TLC)

- WHO stage III disease irrespective of TLC

- WHO stage II disease with a TLC $<$ or $=1200 / \mathrm{mm}^{3}$

Note: $\mathrm{TLC}<$ or $=1200 / \mathrm{mm}^{3}$ does not predict $\mathrm{CD}_{4}$ cell count $<200$ cells $/ \mathrm{mm}^{3}$ in asymptomatic patient: as such, TLC $<$ or $=1200 / \mathrm{mm}^{3}$ may not be used as criteria for the initiation of therapy in asymptomatic patients (WHO Stage I disease)

\section{Pre-Treatment Evaluation}

- Complete history and physical examination

- Laboratory parameters (FBC/ESR, LFT, E\&U, Serum lipids, Urinalysis, and $\mathrm{CD}_{4}$ )

- Clinical and immunological classification

- Ensuring availability of supportive measures (nutritional and psychological)

- Developing patient -specific adherence strategy.

HIV testing should be voluntary and confidential. Appropriate pretest and post test counseling should be provided and informed consent obtained ${ }^{34,35}$. Mandatory HIV testing is not recommended as her cooperation and compliance with care and treatment is essential in the control HIV/AIDS. The HIV positive woman is faced with risk of stigma, discrimination, blame, abuse, abandonment and adverse psychological consequences $^{36}$.

The pretest counseling may be provided in group or oneon-one. This should contain information about HIV/AIDS, mode of transmission, risk factors, available HIV tests/results and treatment. The post test counseling is generally one-on-one. Information on how to remain negative should be emphasized for the HIV negative clients. Those that are HIV positive should be counseled on how to cope with the disease, available treatment, care and support with special reference to prevention of mother-to-child transmission $(\mathrm{PMTCT})^{37}$.

\section{Antiretroviral Therapy}

The criteria for the initiation of antiretroviral therapy
$(A R T)^{38}$ and pre-treatment assessment in the HIV positive patient is shown in Table 2 . Pregnancy in the HIV positive woman is an indication for prophylactic ART irrespective of $\mathrm{CD}_{4}$ count, total lymphocyte count (TLC), viral load or clinical stage of the disease. Antiretroviral therapy is indicated during pregnancy for control of maternal HIV infection and/or prevention of mother-to-child transmission (PMTCT). Table 3 shows the preclinical and clinical profiles of currently available antiretroviral drugs.

While the usefulness of antiretroviral drugs in HIV management has long been established, its effectiveness and safety in preventing perinatal transmission was first demonstrated in 1994 by the Pediatric AIDS Clinical Trial Group (PACTG) Protocol $076^{39}$ in the United States and France. In this study, zidovudine used in the antenatal and intrapartum period and given to the baby for the first 6 weeks was associated with about $67 \%$ reduction in perinatal transmission risk. The effectiveness of other regimens using single or combination antiretrovirals have been demonstrated in other studies ${ }^{40-44}$. 
Table 3. Preclinical and Clinical Data relevant to the use of Antiretroviral Agents in Pregnancy

\begin{tabular}{|c|c|c|c|c|}
\hline Antiretroviral drug & $\begin{array}{l}\text { FDA } \\
\text { Pregnancy } \\
\text { Category }\end{array}$ & $\begin{array}{l}\text { Placental passage } \\
\text { (newborn: mother } \\
\text { drug ratio) }\end{array}$ & $\begin{array}{l}\text { Long-term } \\
\text { animal carcino- } \\
\text { genicity studies }\end{array}$ & $\begin{array}{l}\text { Animal } \\
\text { Studies }\end{array}$ \\
\hline \multicolumn{5}{|c|}{ Nucleoside and nucleotide analog reverse transcriptase inhibitors } \\
\hline $\begin{array}{l}\text { Zidovudine } \\
\text { (AZT, ZDV) }\end{array}$ & $\mathrm{C}$ & $\begin{array}{l}\text { Yes (human) } \\
(0.85)\end{array}$ & $\begin{array}{l}\text { Positive (rodent, } \\
\text { vaginal epithet.) }\end{array}$ & $\begin{array}{l}\text { l } \\
\vdots\end{array}$ \\
\hline $\begin{array}{l}\text { Zalcitabine } \\
\text { (ddC) }\end{array}$ & $\mathrm{C}$ & $\begin{array}{l}\text { Yes (rhesus monkey) } \\
(0.30-0.50)\end{array}$ & $\begin{array}{l}\text { Positive (rodent, } \\
\text { thymic lympho.) }\end{array}$ & I \\
\hline $\begin{array}{l}\text { Didanosine } \\
\text { (ddl) }\end{array}$ & B & $\begin{array}{l}\text { Yes (human) } \\
(0.5)\end{array}$ & $\begin{array}{l}\text { Negative (no tumors, } \\
\text { lifetime rodent study) }\end{array}$ & 1 \\
\hline $\begin{array}{l}\text { Stavudine } \\
(\mathrm{d} 4 \mathrm{~T})\end{array}$ & $\mathrm{C}$ & $\begin{array}{l}\text { Yes (rhesus monkey) } \\
(0.76)\end{array}$ & Not completed & 1 \\
\hline $\begin{array}{l}\text { Lamivudine } \\
\text { (3TC) }\end{array}$ & $\mathrm{C}$ & $\begin{array}{l}\text { Yes (human) } \\
(\sim 1.0)\end{array}$ & $\begin{array}{l}\text { Negative (no tumors, } \\
\text { lifetime rodent study) }\end{array}$ & 1 \\
\hline $\begin{array}{l}\text { Abacavir } \\
\text { (ABC) }\end{array}$ & $\mathrm{C}$ & Yes (rats) & Not completed & ! \\
\hline Tenofovir DF (TDF) & $\mathrm{B}$ & Yes (rat and monkey) & Not completed & 1 \\
\hline \multicolumn{5}{|c|}{ Non-nucleoside reverse transcriptase inhibitors } \\
\hline $\begin{array}{l}\text { Nevirapine } \\
\text { (NVP) }\end{array}$ & $\mathrm{C}$ & $\begin{array}{l}\text { Yes (human) } \\
(\sim 1.0)\end{array}$ & Not completed & 了 \\
\hline $\begin{array}{l}\text { Delavidine } \\
\text { (DLV) }\end{array}$ & $\mathrm{C}$ & Unknown & Not completed & 1 \\
\hline $\begin{array}{l}\text { Efavirenz } \\
\text { (EFV) } \\
\text { Protease inhibitors }\end{array}$ & $\mathrm{C}$ & $\begin{array}{l}\text { Yes (rat and monkey) } \\
(\sim 1.0)\end{array}$ & Not completed & 1 \\
\hline Indinavir(IDV) & $\mathrm{C}$ & Minimal (human) & Not completed & 1 \\
\hline Ritonavir(RTV) & $\mathrm{B}$ & Minimal (human) & $\begin{array}{l}\text { Positive (rodent, liver } \\
\text { tumors in male mice) }\end{array}$ & 1 \\
\hline Saquinavir(SQV) & $\mathrm{B}$ & Minimal (human) & Not completed & 1 \\
\hline Nelfinavir(NFV) & $\mathrm{B}$ & Minimal (human) & Not completed & 1 \\
\hline Amprenavir(APV) & $\mathrm{C}$ & Unknown & Not completed & ] \\
\hline Lopinavir-Rilunavir(L,PV/r & $\mathrm{C}$ & Unknown & Not completed & 1 \\
\hline
\end{tabular}

FDA Food and Drug Administration

A- Human Studies demonstrate safety in pregnancy;

B- Animal studies indicative of safety; C- No human and animal studies or animal studies shows risks;

D- Human risk exist but benefits of use outweighs risk. E- Animal studies indicate risk clearly outweighs benefits Adapted from CDC $^{48}$ 
Table 4

Clinical Settings and Recommendations for the Use of Antiretroviral Drugs in Pregnant Women

\begin{tabular}{|c|c|}
\hline CLINICAL SETTING & RECOMMENDATION \\
\hline 1:HIV-infected pregnant women with indications for ART treatment & 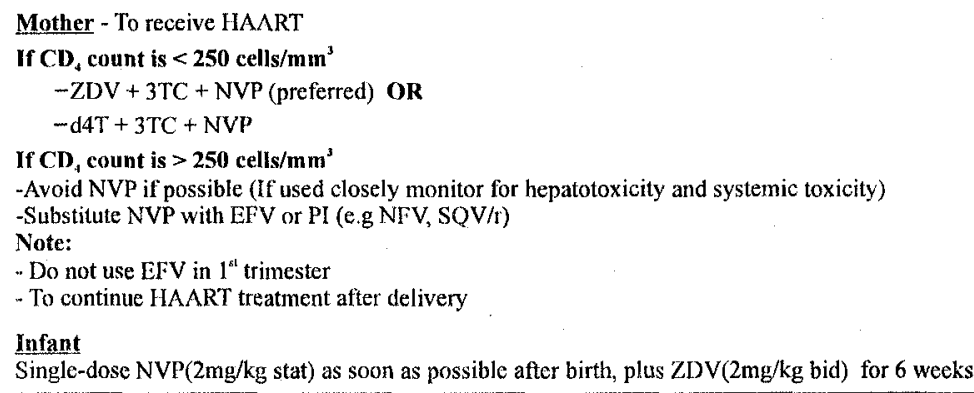 \\
\hline 2:HIV-infected pregnant women without indications for ART treatment & $\begin{array}{l}\text { Mother } \\
\text {-Initiate HAART as above } \\
\text { If HAART is not accessible or feasilbe } \\
\text { - ZDV from week } 28 \text {, continue during labour, plus single dose NVP at onset of labour OR } \\
\text { - ZDV + 3TC from week } 34-36 \text { continue during labour plus singie dose NVP at onset of labour } \\
\text { Infant } \\
\text { Single-dose NVP( } 2 \mathrm{mg} / \mathrm{kg} \text { stat) as soon as possible after birth, plus ZDV( } 2 \mathrm{mg} / \mathrm{kg} \text { bid) for } 6 \text { weeks }\end{array}$ \\
\hline 3: Mother receiving HAART at the time of current pregnancy & $\begin{array}{l}\text { Mother } \\
\text { - To continue HAART } \\
\text { - ZDV should preferably be part of therapy } \\
\text { - EFV is contraindicated in the first trimester } \\
\text { Infant } \\
\text { Single-dose NVP( }(2 \mathrm{mg} / \mathrm{kg} \text { stat }) \text { as soon as possible after birth, plus } Z D V(2 \mathrm{mg} / \mathrm{kg} \text { bid) for } 6 \text { weeks }\end{array}$ \\
\hline $\begin{array}{l}\text { 4:HIV-infected pregnant women diagnosed or seen for the } \\
\text { first time in labour }\end{array}$ & $\begin{array}{l}\text { Mother } \\
- \text { Single-dose NVP followed by }(\mathrm{ZVD}+3 \mathrm{TC}) \text { for } 4-7 \text { days. Mother to be reviewed } \\
\text { within one week of delivery for further assessment and possible commencement of HAART. } \\
\text { Infant } \\
\text { Single-dose NVP( }(\mathrm{mg} / \mathrm{kg} \text { stat }) \text { as soon as possible after birth, plus ZDV }(2 \mathrm{mg} / \mathrm{kg} \text { bid) for } 6 \text { weeks }\end{array}$ \\
\hline 5:HIV-infected mother who presents after delivery & $\begin{array}{l}\text { Mother } \\
\text {-Determine mothers eligibility for HAART and treat appropriately } \\
\text { Infant } \\
\text { Single-dose NVP }(2 \mathrm{mg} / \mathrm{kg} \text { stat }) \text { as soon as possible after birth, plus } \mathrm{ZDV}(2 \mathrm{mg} / \mathrm{kg} \text { bid }) \text { for } 6 \text { wet:ks }\end{array}$ \\
\hline 6:HIV-infected with active tuberculosis & $\begin{array}{l}\text { Mother } \\
\text { Options include: } \\
- \text { ZDV + 3TC + abacavir } \\
\text {-ZDV + 3TC + tenofovir } \\
\text { - ZDV + 3TC + Ritonavir-boosted PIs (Change rifampicin to low-dose rifabutin) } \\
- \text { ZDV + 3TC + EFV (800mg) (If initiated in the third trimester) } \\
\text { Infant } \\
\text { Single-dose NVP(2mg/kg stat) as soon as possible after birth, plus ZDV(2mg/kg bid) for } 6 \text { weeks }\end{array}$ \\
\hline
\end{tabular}

ZDV - Zidovudine $300 \mathrm{mg}$ bid; 3TC - Lamivudine $150 \mathrm{md}$ bid;

NVP - Nevirapine $200 \mathrm{mg}$ daily $x 14$ days, then $200 \mathrm{mg}$ bid;

d4T - Stavudine $>60 \mathrm{~kg}: 40 \mathrm{mg}$ bid, $<60 \mathrm{~kg}: 30 \mathrm{mg}$ bid;

EFV - Efevirence $600 \mathrm{mg}$ daily; ABC - Abacavir 300mg bid;

TDF - Tenofovir DF - 300mg qd; NFV - Nelfinavir 1250mg bid or 750mg tid; SQV/r - Ritonavir-boosted Saquinavir $1000 / 100$ bid

NOTE: Women who decide to breastfeed may continue HAART during the period of breastfeeding.

Adapted from FMOH $^{37}$ and WHO ${ }^{511}$

The more recent development is with combination of three or more antiretroviral drugs (from 2 or more drug class) in the form of highly active antiretroviral therapy (HAART). HAART regimen has revolutionized the management of HIV/AIDS. It ensures maximum suppression of viral replication leading to better maternal health; prevention of perinatal transmission and reduction in potential for development of viral resistance ${ }^{45-47}$. Currently HAART regimen is the standard care for HIV positive pregnant women in developed countries ${ }^{48.49}$.
Table 4 shows the antiretroviral regimen which may be used in various clinical situations in resource constrained settings. The treatment regimen varies both in the number of drugs and duration of treatment. The choice of antiretroviral should be based on issues of efficacy, safety, drug resistance, feasibility and acceptability.

\section{Principles on the use of Antiretrovirals in Pregnancy}

The principles guiding antiretroviral use during pregnancy include: 
- Decisions regarding initiation or alteration of antiretroviral therapy should be the same in pregnant and non-pregnant states. Appropriate counseling to ensure adherence and investigations to determine safety are essential. No woman should be denied antiretroviral on account of pregnancy.

- Previously diagnosed women who are antiretroviral naive and those diagnosed for the first time requiring antiretroviral only for prevention of mother-to-child transmission; may be managed on any of the outlined regimen after due counseling. Those on treatment who do not intend to continue antiretroviral therapy after delivery should discontinue the drugs.

- Women diagnosed for the first time in pregnancy and requiring long-term antiretroviral therapy should preferably start after 1'4 weeks.

- Antiretroviral experienced women on HAART combination therapy who become pregnant may continue this through pregnancy or stop drugs when pregnancy is diagnosed and restart them after 14 weeks gestation.

- Combination therapy is the preferred treatment. However, monotherapy may be justified during pregnancy (for purpose of PMTCT) in situations when combined therapy (HAART) is not accessible or feasible.

Antiretroviral drugs act principally by reducing maternal viral load and serve as pre/post exposure prophylaxis for the infant. As with most drugs, there is concern about potential teratogenic, mutagenic and carcinogenic effects with use of antiretrovirals in pregnancy. Though, short term followup of babies exposed to antiretrovirals has not shown any significant abnormality, long term follow-up data are not yet available. The development of drug toxicity - in form of anemia, mitochondrial toxicity (lactic acidosis, hepatitis, pancreatitis, peripheral neuropathy, myopathy, cardiomyopathy), hyperlipidemia, fat redistribution, insulin resistance and bone disorders (osteopenia, osteoporosis and osteonecrosis) have been documented. The occurrence of drug resistance with some of the antiretroviral drugs has also been established ${ }^{51}$. These developments have affected the use of these drugs.

\section{Antenatal Care}

The antenatal care for an HIV positive woman is not fundamentally different from that of an HIV negative woman. Additional measures are however, taken to reduce the risk of perinatal transmission. The care should be sensitive, supportive, non-discriminatory and not stigmatizing. Where possible a multidisciplinary team of health workers including - obstetricians, general practitioners, nurses/midwives, HIV physicians, pediatricians, social workers, nutritionist and counselors - should be involved.

In countries where the law permits and safe services are available, a pregnant HIV positive woman may opt for termination of pregnancy. However, with increasing expertise in care for HIV positive women, the need for abortion on account of positive sero-status as an only indication is no longer common. An HIV positive woman identified in pregnancy should in addition to her antenatal care be evaluated and managed appropriately for HIV related illnesses and opportunistic infections. Special attention should be paid to respiratory tract infections, persistent diarrhea, urinary tract infections, oral/vaginal candidiasis, sexually transmitted infections, herpes zoster, and weight loss. Where possible, laboratory investigations should include serial full blood count, screening for sexually transmitted infections (syphilis, Chlamydia, gonorrhea, hepatitis B and $\mathrm{C}), \mathrm{CD}_{4}$ count, and quantitative viral load assessment.

Based on investigation findings, appropriate treatment should be offered. Iron, folic acid and multivitamin supplements are particularly necessary as anemia is common in HIV patients. More so, some antiretroviral drugs are associated with bone marrow suppression. Multivitamin supplementation has been shown to increase maternal $\mathrm{CD}_{4}$ and $\mathrm{CD}_{8}$ counts, reduce stillbirths, severe preterm births, low birth weights and small-for-gestational age rates ${ }^{52}$. Antimalarial prophylaxis (especially intermittent preventive therapy using sulfadoxine - pyrimethamine) is essential in HIV positive pregnant women to reduce placental malaria infection, which may increase perinatal transmission risk $^{53}$.

When the $\mathrm{CD}_{4}$ count is below 200 cell $/ \mathrm{mm} \mathrm{m}^{3}$ and the risk of tuberculosis and/or pneumocystis carinii pneumonia is high, appropriate chemoprophylaxis with isoniazid and/or co-trimoxazole is necessary ${ }^{48}$. Nutrition and other social support should be addressed in the course of the antenatal period. She should be counseled on appropriate lifestyle and behavioral change including safer sex practices, avoidance of smoking and hard drug use. Counseling on infant feeding options, mode of delivery and antiretroviral use are also essential to enable informed decision by the patient.

Specific obstetric measures as part of antenatal care for HIV positive women include - avoidance of invasive procedures such as chorionic villus sampling, amniocentesis, cordocentesis and external cephalic version in breech presenting fetus - which tends to increase the risk of HIV transmission to the fetus ${ }^{44}$. 
The involvement of the partner is essential in order to determine their status and elicit support for care of the woman and in infant feeding choice.

\section{Intrapartum Care}

The period of labour is a particularly stressful time for the HIV positive patient. They are concerned about the risk of transmission to the child, about possible stigmatization and their own uncertain future. They therefore need support and encouragement.

The need for reduction in perinatal transmission has influenced decision for use of elective caesarean delivery in HIV positive women. Elective caesarean section has been associated with over $50 \%$ reduction in the risk of perinatal transmission ${ }^{23,24}$. However, recent reports suggest that caesarean section can be avoided if HAART is used to maximally suppress maternal viral load (HIV-1 RNA level) to $<1000$ copies $/ \mathrm{ml}^{48}$. Given the low risk of transmission with vaginal delivery amongst women on antiretroviral therapy with very low viral load, it is surmised that the benefit of caesarean delivery in reducing transmission though still present would be of small magnitude ${ }^{54}$. Any benefit must be weighed against the known increased risks to the woman with caesarean section compared with vaginal delivery i.e several fold increased risk of postpartum infections, including uterine infections and pneumonia, anesthesia risks, and surgical complications ${ }^{55}$. When Caesarean section is the chosen mode of delivery, it should be undertaken before the onset of labour and prior to rupture of membranes. The use of prophylactic antibiotics is essential to prevent infections which tend to be common in situations of immune-deficiency.

When vaginal delivery is the preferred option, some modifications to standard obstetric practice (through minimizing the exposure of the infant to infected maternal blood and cervico-vaginal secretions) have been associated with reduction in the risk of perinatal transmission ${ }^{21}$. These include:

- Avoidance of prolonged rupture of membrane ( $>$ 4hours). Artificial rupture of membranes should be avoided as much as possible until second stage of labour.

- Regular swabbing of the vagina with $0.25 \%$ chlorhexidine

- Avoidance of invasive procedures that breaks the baby's skin, such as penetrating scalp electrodes or scalp blood sampling.

- Avoidance of instrumental deliveries. Vacuum extraction is associated with microlacelerations of the scalp

- Early clamping of the cord and early cleansing/bathing of the baby to remove maternal blood and secretions. The baby may be washed with a warm chlorhexidine solution.

\section{Postnatal Care}

In addition to the general postpartum care, the mothers should be counseled and supported on the following:

- The infectiousness of lochia and blood stained sanitary pads and materials, and advised on how to dispose of these safely according to the local facilities.

- Infant feeding choice

- Perineal care and breast care to avoid infectious complications.

- Family planning and reproductive health care services. This is of particular importance if the patient chooses not to breastfeed as the contraceptive effect of lactational amenorrhea will be absent. Dual protection contraception (i.e. the male condom or the female condom alone or combined with other methods) is advocated to protect from STIs/HIV infections and unplanned pregnancy.

- Yearly cervical smear is also advised as they are at higher risk of developing cervical dysplasia and carcinoma.

- The need to stop smoking or alcohol and hard drug use

- Nutritional advice for heaithy diet, using locally available foods

Regular medical follow-up in the postnatal period is essential for diagnosis and treatment of any complications. If possible, monitoring of viral load and $\mathrm{CD}_{4}$ count should be undertaken to determine the clinical stage of the disease. The patient is eventually referred to a specialized HIV/AIDS or infectious disease service for further management. This may include highly active antiretroviral therapy and prophylaxis for opportunistic disease(s) with development of AIDS or when $\mathrm{CD}_{4}$ count becomes less than 200 cell $/ \mathrm{mm}^{3}$. The patients should also be provided social and psychological support within local facilities or referred to organized support groups, community based organizations and non-governmental organizations.

\section{Care for the HIV-Exposed Infant}

Children born to HIV positive mothers should be cared for to prevent HIV transmission and maintain their well being. Appropriate care should include:

- Proper handling with gloves until maternal blood and secretions are washed off.

- Prophylaxis for ophthalmia neonatorum such as 
use of $1 \%$ silver nitrate or antibiotic eye ointment should be given

- Antiretroviral therapy should be commenced as soon as possible (not later than 72 hours) using Single-dose NVP (2mg/kg stat) plus ZDV ( $2 \mathrm{mg} / \mathrm{kg}$ bid) for 6 weeks $^{37,56}$.

- Option of infant feeding accepted by the mother following counseling in the antenatal period should be commenced. In developed countries mothers are advised not to breastfeed. ${ }^{48,49}$ While, this is the best option in protecting the baby from HIV infection, issues of cost, safe preparation and cultural practice make many women in developing countries to breastfeed. Appropriate micronutrient supplementation is required for babies on infant formula $a^{57}$. Mixed feeding should be discouraged as it is associated with increased risk of HIV transmission.

- Full immunization, following the standard immunization schedule should be given.

- Regular growth monitoring follow-up visits to coincide with immunization schedules

- The diagnosis of HIV should be made as soon as possible. This is so that infected babies can benefit from antiretroviral therapy and prophylaxis for opportunistic infections. Diagnosis is made after 15 months using ELISA or simple/rapid test when acquired maternal antibodies have disappeared from infant circulation. The diagnosis can be made earlier in the child (2-3 months), using polymerase chain reaction (PCR) techniques which detect and/or measure the viral load. The $P_{24}$ antigen test may also be used. In all cases informed consent of the mother (or parents) should be obtained.

\section{Universal Precaution}

Though the risk of nosocomial HIV infection to the health worker is small $(0.2 \%$ following needle stick

\section{References}

1. Taha TE, Dalbetta GA, Hoover DR, Chiphangwi JD, Mtimavalye LA, Liomba GN, et al. Trends of HIV-1 and sexually transmitted diseases among pregnant and postpartum women in urban Malawi. AIDS, 1998, 12(2):197-203

2. Nnatu SN, Anyiwo CE, Obi CL, Karpas A. Prevalence of Human Immunodeficiency Virus (HIV) antibody among apparently healthy pregnant women in Nigeria. Int J Gynaecol Obstet, 1993;40(2):105-7

3. Harry TO, Bukbuk DN, Idrisa A. and Akoma B. HIV infection among Pregnant Women: A worsening situation in Maiduguri, Nigeria. Trop Geograph Med, 1994:46(1)

4. Agboghoroma OC, Efetie ER, Iregbu KCHIV in pregnancy: Prevalence rate at the National Hospital, Abuja, Nigeria. The $3^{\text {id }}$ Conference on Global Strategies for the prevention of HIV transmission from mothers to infants, Kampala, Uganda (Abst 238) September 9 13, 2001

5. Federal Ministry of Health. 2003 National HIV Seroprevalence Sentinel survey. Technical report. AIDS/STD Control Programme. Federal Ministry of Health, Abuja 2004.

6. French $\mathrm{R}$, Brocklehurst $\mathrm{P}$, The Effect of pregnancy on Survival in Women Infected with HIV: A systematic review of the literature and meta-analysis. BrJObst Gynaecol, 1998 105:827-35 injury compared with $25 \%$ with a patient who is hepatitis $\mathrm{B}$ e antigen positive) universal precautions should be observed. In particular wearing of double gloves; use of water proof gowns and boots; the wearing of eye shield and proper use and disposal of sharps are recommended. Safe disposal of waste and proper decontamination and sterilization of equipment are also necessary ${ }^{58}$. The use of combination antiretroviral drugs as post exposure prophylaxis after significant occupational exposure to HIV is also recommended ${ }^{59}$.

\section{Conclusion}

The management of HIV in pregnancy has evolved overtime. With appropriate use of antiretroviral drugs, modifications in obstetrics care and infant feeding, it is now possible to maintain optimal maternal health and prevent perinatal transmission. However, there are many constraints in delivering this care in developing countries where HIV is most prevalent. Health care infrastructures are not well developed, the coverage and utilization of antenatal and delivery services are low. High cost of antiretroviral drugs restricts access for many infected women, while erratic supply of antiretroviral drugs leads to poor adherence to drug schedule. These will ultimately culminate in the emergence of drug resistance and its consequences.

The provision of effective care to HIV positive pregnant women is therefore a major challenge to health workers, programme managers and policy makers in developing countries. It requires resource mobilization to improve access to, and quality of reproductive health care with integrated HIV management. It will also require training and re-training of health workers at all levels to enhance institutional capacity in providing these services. It is imperative that health workers are more sensitive to research information to enable the benefits of new scientific information on HIV management are translated to clinical care without much delays.

7. Brocklehurst P, French R. The Association between maternal HIV infection and perinatal outcome: A systematic review of the literature and meta-analysis. BrJObst Gynaecol 1998 105:836-848.

8. UNAIDS and WHO. AIDS Epidemic Update: December 2004 UNAIDS/04.45E, Geneva 2004.

9. De Cock KM, Fowler MG Mercier E, de Vincenzi I, Saba J, Hoffe, et al. Prevention of Mother-to-Child HIV transmission in resource poor countries: translating research into policy and practice. JAMA 2000; $283(9) ; 1175-1182$

10. The Working Group on Mother to Child Transmission of HIV. Rates of Mother-to-Child Transmission of HIV-I in Africa, America and Europe: Result from 13 perinatal studies J. Acquir Immune Defic Syndr Hum Retroviral $1995 ; 8: 506-510$.

11. Bertolli J, Louis ME, Simonds RJ, Njeburg P, Kamenga M, Brown C, et al: Estimating the timing of Mother-to-Child Transmission of HIV in a breast feeding Population in Kinshasha, Zaire. J Infect Dis 1996: 174:722-726

12. Rouzious C, Costagliola D, Burgard M, Blanche S, Mayaux MJ, Griscelli $S$, et al. Estimating timing of Mother-To-Child Human Immunodeficiency Virus type 1 (HIV-1) transmission by use of a Markov Model: The HIV infection in Newborns French Collaboration Study Group, Am J Epidemiol 1995; 142: 1330-1337 
13. Dunn DT, Newell ML, Ades AE, Peckham CS. Risk of Human Immunodeficiency Virus type 1 transmission through breast-feeding. Lancet 1992; 340:585-588

14. Garcia PM. Kalish IA, Pitt J, Minkoff H, Quinn TC, Burchett SK, et al. Maternal levels of plasma human immunodeficiency virus type I RNA and the risk of nerinatal transmission. NEngl JMed 1999; 341:394-420.

15. Thea DM, Steketee RW, Pliner V, Bomschlegel K, Brown T, Orliff S, et al. The effect of maternal viral load on the risk of perinatal transmission of human immunodeficiency virus - 1 AIDS, 1997; 11:437-444

16. O'Shea S, Newell ML, Dunn DT, Garcia-Rodriguez MC, Bates I., Mullen $\mathrm{J}$, et al. Maternal viral load, $\mathrm{CD}_{4}$ cell count and vertical transmission of HIV-1 JMed Virol, 1998; 54: 113-117.

17. European Collaborative Study. Vertical transmission of HIV-1: maternal immune status and obstetric factors AIDS 1994; 10: 1675-1681

18. Matheson PB, Thomas BA, Abrams EJ, Pliner V, Lambert G, Bamji M, et al. Heterosexual behaviour during pregnancy and perinatal transmission ofHIV-1. AIDS, 1996; 10: 1249-1256.

19. Rodriguez EM, Mofenson LM, Chang BH, Rich KC, Fowler MG, Smeriglio V, et al. Association of maternal drug use during pregnancy with maternal HIV culture positivity and perinatal transmission. AIDS, 1996; 10(3): 273-282

20. Semba RD, Motti PG, Chipwangiwi JD, Saah AJ, Canner JK, Dallagetta $G A$ et al. Maternal Vit A deficiency and mother-to-child transmission of HIV-1. Lancet, 1994; 343: 1593-1597.

21. Landesman SH, Kalish L, Burns DN, Minkoff H, Fox HE, Zorrilla C, et al Obstetrical factors and transmission of human immunodeficiency virus from mother-to-child. NEngl.JMed, 1996;334: 1617-1623

22. Minkoff H, burns DN, Landesman S, Youchah J, Goedert JJ, Nugent RP, et al. The relationship of the duration of ruptured membranes to vertical transmission of human immunodeficiency virus. Am J Obstet Gynecol, $1995 ; 173: 585-58$

23. International Perinatal HIV Group. The Mode of delivery and the risk of vertical transmission of HIV-I: A meta-analysis from fifteen prospective Cohort studies (the International Perinatal HIV Group) N Engl. Med, 1999 340: $977-987$.

24. Tovo PA, de Martino M, Gabiano C, galli L, Cappello N, Ruga E, et al. Mode of delivery and gestational age influence perinatal perinatal HIV-1 transmission. J Acquir Immune Defic Syndrome Human Retroviro, 1996; 11:88-94.

25. RuffAJ, Coberly J, Halsey NA, Boulos R, Desormeaux J, Burnley A, et al. Prevalence of HIV-I DNA and p24 antigen in breast milk and correlation with maternal factors. J Acquir Immune Defic syndr, 1994; 7: 68-73.

26. Datta P, Embree JE, Kreiss JK, Ndinya-Achola JO, Braddick M Temmerman $M$, et al. Mother-to-child transmission of human immunodeficiency virus type 1: report from the Nairobi study. $J$ Infect Dis, 1994; 170: 1134-1140.

27. Coutsoudis A, Pillay K, Spooner E, Kuhn L, Coovadia HM Influence of infant feeding patterns on early mother-to-child transmission of HIV-I in Durban, South Africa: a prospective Cohort study. South African vitamin A study Group Lancet, 1999, 354:471-476.

28. Johnson F. Management of pregnancy in women with HIV infection. BritishJHosp Med, 1992; 48(10): 664-670.

29. Kass NE, Taylor HA, Anderson J. Treatment of human immunodeficiency virus during pregnancy: The shift from an exclusive focus on fetal protection to a more balanced approach. Am J Obstet Gynecol, 2000; 182 856-9.

30. Watts DH. Management of Human Immunodeficiency Virus Infection in Pregnanacy. NEnglJMed, 2002; 346(24):1879-1891

31. Johnson F. HIV and Pregnancy: National and International perspectives In: O'Brien PMS (ed), Yearbook of Obstetrics and Gynaecology, Volume 8. Royal College of Obstetricians and Gynaecologists (RCOG) Press, London 2000; 143-153

32. Piot P, Coll-Seck A. Preventing mother-to-child transmission of HIV in Africa. Bulletin of the.World Health Organization, 1999;77(11):869-870.

33. Berer M. Reducing perinatal HIV transmission in developing countries through antenatal and delivery care, and breastfeeding: Supporting infant survival by supporting women's survival. Bulletin of the World Health Organization, 1999;77(11):871-877

34. UNAIDS. Voluntary Counselling and Testing (VCT); UNAIDS Technical Update. Geneva. May 2000

35. Federal Ministry of Health. National Guidelines for HIV/AIDS Voluntary Counselling and Testing, Abuja 2003

36. Lester $\mathrm{P}$, Partridge J, Chesney $M$, Cooke $M$. The consequences of a positive prenatal HIV antibody test for women. Women of AIDS and human retrovirology 1995; 10 (3) $341-349$

37. Federal Ministry of Health. National Guidelines for the implementation of prevention of mother to child transmission of HIV (PMTCT). National AIDS/STD Control Programme, Federal Ministry of Health, Lagos, 2005
38. Federal Ministry of Health. Guidelines for the use of antiretroviral (ARV) drugs in Nigeria. FMOH, Abuja. 2001

39. Connor EM Sperling RS, Gelber R, Kiselev P, Scott G, O'Sullivan MJ et al. Reduction of maternal- infant transmission of human immunodeficiency virus type I with Zidovudine treatment. $N$ Engl J Med, 1994; 331 (14) 1173-1180

40. Shaffer N, Chuachoowong R, Mock PA, Bhadrafom C, Siriwasin W, Young NL, et al. Short Course Zidovudine for perinatal HIV-I transmission in Bangkok, Thailand: A randomized controlled trial. Lancet, $1999 ; 353: 773-780$.

41. Wiktor SZ, Ekpini E, Karon JM, Nkengasong J, Maurice C, Severin ST, et al. Short course oral Zidovudine for prevention of Mother-to-Child transmission of HIV-I in Abidjan, Cote d'Ivoire: A randomized trial Lancet, 1999; 353:781785.

42. Guay LA, Musoke P, Fleming T, Bagenda D, Allen M, Nakabiito C, et al. Intrapartum and neonatal single-dose nevirapine compared with Zidovudine for prevention of mother-to-child transmission of HIV-1 in Kampala: HIVNET 012 randomised trial. Lancet, 1999; 354: 795-802.

43. Dorenbaum A, Cunningham CK, Gelber RD, Culnane M, Mofenson L, Britto $P$ et al. Two-dose intrapartum/newborn nevirapine and standard antiretroviral therapy to reduce perinatal HIV transmission. A randomized trial. $J A M A, 2002 ; 288: 189-198$

44. Chaisilwattana $P$, Chokephaibulkit $K$, Chalermchockcharoenkit $A$, Vanprapar N. Sirimai K, Chearskul S et al. Short - course therapy with zidovudine plus lamivudine for prevention of mother-to-child transmission of human immunodeficiebcy virus type 1 in Thailand. Clin Infect Dis, 2002; 35: 1405-1413

45. Cooper ER, Charurat M, Mofenson L, Hanson Cl, Pitt J, Diaz C, et al Combination antiretroviral strategies for the treatment of pregnant HIV-I infected women and prevention of perinatal HIV-1 transmission. $J$ Acquir Immune Def Syndr, 2002; 29:484-494.

46. Shaffer $N$. Combination prophylaxis for prevention of maternal-infant HIV infection. JAMA, 2001; 285:2129-2131.

47. Cooper E, Charurar M, Burns DN, Blattner W, Hoff R. Trends in antiretroviral therapy and mother-infant transmissioin of HIV. The Women and Infants Tranasmission Study Group. J Acquir Immune Defic Syndr, 2000;24(1):45-7

48. Centres for Disease Control and Prevention. United States Public Health Service Task Force Recommendations for use of Antiretroviral drugs in pregnant HIV-1 Infected women for maternal health and Interventions to reduce perinatal HIV-1 transmission in the United States. MMWR 2002; 51 (No.RR-18)

49. Royal College of Obstetricians and Gynaecologists. Management of HIV in pregnancy. Guideline No. 39, 2004. RCOG, London.

50. World Health Organization. Antiretroviral Drugs for Treating Pregnant women and Preventing HIV infection in Infants. Guidelines on Care, Treatment and Support for Women living with HIV/AIDS and their children in resource-constrained settings. World Health Organization, Switzerland, 2004

51. Eshleman SH, Mracna M, Guay LA, Deseyve M, Cunninham S, Mirochnick $M$, et al. Selection and fading of resistance mutations in women and infants receiving nevirapine to prevent HIV-1 vertical vertical transmission. (HIVNET 012). AIDS 2001;15;1951-1957

52. Fawzi WW, Msamanga GI, Spiegelman D, Urassa EJN, McGrath N, Mwakagile D, et al. Randomised trial of effects of vitamin supplements on pregnancy outcomes on T-cell counts in HIV-I infected women in Tanzania. The Lancet 1998; 351: 1477-1482.

53. Ayisi JG, Van Ejik AM, Newman RD, ter Kuile FO, Shi YP, Yang C, et al. Maternal malaria and perinatal HIV transmission. Emerg Infect Dis, 2004 A pr: $10(4)$ [serial online]. Available at http://www.cdc,gov/ncidod/EID/vol 10 no 4/03-0303-htm

54. Clarke SM, Mulcahy F, Healy CM, Condon S, Butler KM. The efficacy and tolerability of combination antiretroviral therapy in pregnancy: infant and maternal outcome. Int J STD AIDS, 2000;11:220-3.

55. van Ham MA, van Dongen PwJ, Mulder J. Maternal consequences of caesarean section. A retrospective study of intra-operative and postoperative maternal complications of caesarean section during a 10-year period. Eur JObstet Gynecol Reprod Biol, 1997; 74: 1-6.

56. Grange AO, Iroha EO, Akinsulie AO, Temiys EO, Ezeake VC, Adetifa IMO. Guidelines for the management of HIV/AIDS in Infants and older children in Lagos University Teaching Hospital. Nig. Qt $J$ Hosp Med, $2003 ; 13(1-2): 8-13$.

57. Federal Ministry of Health. Guidelines on infant feeding and HIV/AIDS in Nigeria. Federal Ministry of Health, Abuja. 2001

58. A toyebi OA. Protection of Health workers from occupational Hazards of HIV Infections. Nig Med J, 1998; 34 suppl: 59-64.

59. Keshinio B Management of Occupational exposure to the Human immurodeficiency virus. Ann Afr Med, 2003;2:1-5 